\title{
Nitrogen Assimilation by Bacillus licheniformis Organisms Growing in Chemostat Cultures
}

\author{
By J. L. MEERS* AND L. KJAERGAARD PEDERSEN \\ Department of Enzyme Microbiology, Novo Industri A/S, Fuglebakkevej 215, \\ 2200 Copenhagen $N$, Denmark
}

(Accepted for publication 6 November 197I)

SUMMARY

Medium composition influenced the synthesis and breakdown of glutamic acid and alanine by Bacillus licheniformis examined in a chemostat. With ammonia in growth-limiting quantities as the sole nitrogen source, glutamate was synthesized from 2-oxoglutarate via glutamine synthetase and glutamine amide 2-oxoglutarate amino transferase (NADP; oxidoreductase), and alanine was formed from glutamate and pyruvate by transamination. With excess nitrogen, as either alanine or glutamate, a carbon-limited culture synthesized respectively NAD-linked alanine dehydrogenase or NADP-linked glutamate dehydrogenase, and the latter two enzymes performed only a catabolic role. If, however, nitrogen was supplied as alanine or glutamate to a nitrogen-limited culture, then synthesis of alanine dehydrogenase and glutamate dehydrogenase was repressed. Correlations were drawn between the nature of the growth environment, the composition of the amino acid pools and the synthesis of the above mentioned enzymes in $B$. licheniformis.

\section{INTRODUCTION}

In bacteria, the biosynthesis of 2-amino acids from ammonia is generally supposed to occur through the reductive amination of the corresponding 2-keto acids, these reactions being catalysed by the amino acid dehydrogenases, principally glutamate dehydrogenase (GD) (EC I . 4. I .4) but also alanine dehydrogenase (AD) (EC I . 4. I I) (see, for example, Goldman, I959; Meister, 1965; Germano \& Anderson, 1968). Hong, Shen \& Braunstein (1959) found that glutamate dehydrogenase-deficient mutants of some Gram-positive bacteria could readily grow and assimilate ammonia providing they contained alanine dehydrogenase; therefore they concluded that organisms of the genus Bacillus could synthesize alanine by direct amination of pyruvate, and thence glutamate, by transamination. However, the importance of GD in ammonia assimilation has been stressed by, amongst others, Piérard \& Wiame (1960). Freese \& Oosterwyk (1963) concluded that, in addition to its main role in ammonia assimilation, a physiological function of AD was to catalyse the catabolism of $\mathrm{L}$-alanine, since $\mathrm{AD}^{+}$but not $\mathrm{AD}^{-}$strains of Bacillus subtilis could utilize L-alanine as a source of carbon and nitrogen.

Recently an alternative pathway for ammonia assimilation has been discovered in which $\mathrm{AD}$ and GD do not participate (Tempest, Meers \& Brown, 1970). Aerobacter aerogenes organisms produced glutamic acid by the synthesis of glutamine from glutamic acid and ammonia, followed by the reductive transfer of the glutamine amide nitrogen to 2-oxo-

* Present address: Research and Development Department, Agricultural Division, ICI, Billingham, Teesside. 
glutaric acid. These two reactions were catalysed by the enzymes glutamine synthetase (EC 6.3 I.2) and glutamine amide 2-oxoglutarate amino transferase (GOGAT).

Previous investigations into the control of synthesis of AD and GD used strains of bacteria which probably also synthesized GOGAT, and the presence of this enzyme would affect the validity of the conclusions drawn by previous authors. The original work on GOGAT (Tempest et al. 1970) was done with Aerobacter aerogenes, a species which lacks AD (Wiame, Piérard \& Ramos, 1962; Tempest et al. 1970). Therefore it seemed appropriate to reinvestigate the physiological relationship between $A D, G D$ and GOGAT in a species that may (and, indeed, does) contain all three enzymes. The present communication reports the results of such an investigation using a strain of Bacillus licheniformis.

\section{METHODS}

Organism. Bacillus licheniformis (NCIB 80I6) was maintained on nutrient agar slopes by monthly subculture at $30^{\circ}$.

Cultural conditions. The organisms were grown in 31 chemostats based on the Biotec FL 103 laboratory fermenter (Biotec AB, Postbox 16152, Stockholm 16, Sweden). Media were designed to give about $2 \mathrm{mg}$ dry bacteria/ml (Evans, Herbert \& Tempest, 1970). The culture was maintained automatically at $\mathrm{pH} 7 \cdot 0$ by the addition of $4 \mathrm{M}-\mathrm{NaOH}$. The temperature was maintained at $34^{\circ}$ throughout, and the air flow rate adjusted to give an oxygen solution rate greater than $250 \mathrm{~mm}-\mathrm{O}_{2} / \mathrm{l} / \mathrm{h}$ - more than that required to maintain fully aerobic growth (Pirt, 1957). The rate of flow of medium into the growth vessel was regulated at the required value using a Watson-Marlow MHRE Mk. 3 pump (Watson-Marlow Ltd, Falmouth, Cornwall).

Extraction of enzymes. Culture effluent was collected directly from the fermenter, and the organisms were harvested and washed (once in chilled $\mathrm{I} \%(\mathrm{w} / \mathrm{v}) \mathrm{NaCl}$ ) by centrifuging at $4^{\circ}$. Extracts were then prepared by disrupting suspensions (about $50 \mathrm{mg}$ dry wt of organisms $/ \mathrm{ml}$, in $50 \mathrm{~mm}$-tris- $\mathrm{HCl}$ buffer, $\mathrm{pH} 7.6$ plus Io mM-mercaptoethanol) in a sonicator (Biosonik III, Bronwell Scientific, Rochester, New York 14603 , U.S.A.) at $60 \%$ of maximum power for Io min at $4^{\circ}$. The bacterial paste was centrifuged $\left(30 \mathrm{~min}\right.$ at $\left.10,000 \mathrm{~g}, 4^{\circ}\right)$ to sediment the unbroken organisms and debris, and the resulting supernatant fluid was dialysed overnight at $4^{\circ}$ against the tris buffer containing mercaptoethanol as specified above. A clear fluid was obtained which contained about $20 \mathrm{mg}$ protein $/ \mathrm{ml}$ and the required enzymes.

Assays of enzyme activity. GD and GOGAT were assayed, and pH activity curves determined by the spectrophotometric methods described previously (Meers, Tempest \& Brown, I97I). AD activities were assayed using the method of Yoshida \& Freese (1965). $K_{m}$ values were determined by conventional methods (Dixon \& Webb, 1964).

Analytical procedures. The free amino acid pool content and composition was assessed by the method described previously (Tempest, Meers \& Brown, 197I), except that a JEOLCO amino acid analyser (model 5/AH; 84 Vesterbrogade, I620 Copenhagen V, Denmark) was used in conjunction with an electronic integrator (JEOLCO, model DK). Protein was estimated by the Biuret method of Stickland (I95I).

\section{RESULTS}

Bacillus licheniformis ( $\mathrm{NCIB} 8 \mathrm{oI} 6$ ) was selected as a representative Gram-positive bacillus able to grow well on a defined simple salts medium and produce $A D, G D$ and GOGAT. 
Table I. Michaelis constants for some of the substrates for alanine dehydrogenase $(A D)$, glutamate dehydrogenase $(G D)$ and glutamine amide, 2-oxoglutarate amino transferase $(G O G A T)$ measured at the appropriate optimum $\mathrm{pH}$ values for maximum activity

\begin{tabular}{|c|c|c|c|c|c|c|}
\hline \multirow[b]{2}{*}{ Enzyme } & \multirow[b]{2}{*}{$\begin{array}{l}\text { Optimum } \\
\text { pH value }\end{array}$} & \multicolumn{5}{|c|}{ Michaelis constants (mM) for } \\
\hline & & Ammonia & Glutamine & Pyruvate & $\begin{array}{l}\text { 2-oxo- } \\
\text { glutarate }\end{array}$ & Alanine \\
\hline $\mathrm{AD}$ (aminating) & $7 \cdot 6$ & 300 & - & 0.33 & - & - \\
\hline GD (aminating) & $8 \cdot I$ & 12 & - & - & $1 \cdot 7$ & - \\
\hline GOGAT & $8 \cdot 0$ & 一 & $3 \cdot 0$ & - & 0.5 & $\ldots$ \\
\hline $\mathrm{AD}$ (deaminating) & $9 \cdot 5$ & - & - & - & - & $I \cdot 2$ \\
\hline
\end{tabular}

Properties of alanine dehydrogenase, glutamate dehydrogenase and glutamine amide 2-oxoglutarate amino transferase measured with the primary substrates

The effect of $\mathrm{pH}$ on the activity of AD, GD and GOGAT was examined with extracts of glucose-limited Bacillus licheniformis organisms $\left(D=0.2 \mathrm{~h}^{-1}\right)$. Each enzyme had a marked optimum (in the aminating reaction) near to $\mathrm{pH} 7.6$ (Table $\mathrm{I}$ ), and this value was selected for use in the routine enzyme assays. The optimum $\mathrm{pH}$ for the activity of the $\mathrm{AD}$ from Bacillus subtilis is lower for the amination reaction than for the deamination reaction (Yoshida \& Freese, 1965), and the same was true for the enzyme from Bacillus licheniformis (Table I).

The rates of the three enzymatic reactions were examined as functions of the concentration of the appropriate amino donor and 2-keto acid substrates, and typical Michaelis-Menten relationships were observed (Table $\mathrm{I}$ ).

The aminating activity of $\mathrm{AD}$ was $50 \%$ inhibited by $10^{-5} \mathrm{M}$-alanine and the deaminating activity was $50 \%$ inhibited by $\mathrm{I}^{-6} \mathrm{M}$-pyruvate, but no inhibition was detectable with less than $10^{-4} \mathrm{M}$-ammonia. Similar results were obtained by Goldman (I959), who proposed reaction mechanisms for $\mathrm{AD}$ which explain the differential inhibition by ammonia and pyruvate. GD and GOGAT were inhibited in their aminating activity by glutamate to an extent similar to that described previously for the enzymes from other species of bacteria (Meers et al. 1971).

Potassium or magnesium ions inhibited the activity of all three enzymes. The extent of inhibition (by given concentrations of the metal ions) was quantitatively similar to previously reported data for AD from Bacillus subtilis (Yoshida \& Freese, 1965) and for GOGAT and GD from various bacterial species (Meers et al. 1971). The inactivation by metal ions was reversed by cysteine or mercaptoethanol, and the latter compound (at Io mM concentration) was incorporated into all of the buffers used during the extraction, dialysis, and determination of the enzymes, as described in Methods.

$\mathrm{AD}$ was specific for $\mathrm{NAD}^{+}$, whereas GD and GOGAT were specific for $\mathrm{NADP}^{+}$; no reaction was observed with the alternative coenzymes.

The 'steady state' levels of $A D, G D$ and GOGAT in chemostat cultures of Bacillus licheniformis

When growing in the magnesium-limited medium (containing glucose and ammonia) Bacillus licheniformis synthesized AD, GD and GOGAT (Table 2). However, of the three enzymes, only GD had high specific activity when compared with the activities of each enzyme under most other growth conditions. This observation is consistent with the suggestion (Meers et al. 197I) that, under conditions of ammonia excess, bacteria use the enzyme 
Table 2. The activities of alanine dehydrogenase $(A D)$, glutamate dehydrogenase $(G D)$ and glutamine amide, 2-oxoglutarate amino transferase (GOGAT) in Bacillus licheniformis

\begin{tabular}{|c|c|c|c|c|c|c|}
\hline \multirow[b]{2}{*}{$\begin{array}{l}\text { Growth-limiting } \\
\text { factor }\end{array}$} & \multirow[b]{2}{*}{$\begin{array}{l}\text { Energy } \\
\text { source }\end{array}$} & \multirow[b]{2}{*}{$\begin{array}{l}\text { Nitrogen } \\
\text { source }\end{array}$} & \multirow[b]{2}{*}{$\begin{array}{l}\text { Dilution } \\
\text { rate }\left(\mathrm{h}^{-1}\right)\end{array}$} & \multicolumn{3}{|c|}{ Specific activities of } \\
\hline & & & & $\mathrm{AD}$ & GD & GOGAT \\
\hline Magnesium & Glucose & Ammonia & $\begin{array}{l}0.04 \\
0.31\end{array}$ & $\begin{array}{l}21 \\
\text { I } 4\end{array}$ & $\begin{array}{l}14 \\
42\end{array}$ & $\begin{array}{r}6 \\
\text { I I }\end{array}$ \\
\hline Carbon & Glucose & Ammonia & $\begin{array}{l}0.05 \\
0.19\end{array}$ & $\begin{array}{r}75 \\
134\end{array}$ & $\begin{array}{r}9 \\
33\end{array}$ & $\begin{array}{l}\text { I I } \\
17\end{array}$ \\
\hline Carbon & Alanine & Alanine & $\begin{array}{l}0.05 \\
0.10 \\
0.20\end{array}$ & $\begin{array}{l}4500 \\
4700 \\
4700\end{array}$ & $\begin{array}{r}7 \\
19 \\
34\end{array}$ & $\begin{array}{l}28 \\
26 \\
22\end{array}$ \\
\hline Nitrogen & Glucose & Ammonia & $\begin{array}{l}0.05 \\
0.10 \\
0.22\end{array}$ & $\begin{array}{l}38 \\
53 \\
37\end{array}$ & $\begin{array}{r}<5 \\
<5 \\
12\end{array}$ & $\begin{array}{l}\text { I I } \\
20 \\
4 I\end{array}$ \\
\hline Nitrogen & $\begin{array}{l}\text { Glucose/ } \\
\text { alanine }\end{array}$ & Alanine & $\begin{array}{l}0.05 \\
0.19\end{array}$ & $\begin{array}{l}\text { I } 8 \\
\text { I } 52\end{array}$ & $\begin{array}{l}<5 \\
<5\end{array}$ & $\begin{array}{l}21 \\
24\end{array}$ \\
\hline
\end{tabular}

GD to aminate 2-oxoglutarate directly to glutamate. However, GOGAT activity was low but none the less appreciable in these magnesium-limited organisms (Table 2), and it is possible that in this species the cyclic mechanism for nitrogen assimilation (Tempest et al. I970) was responsible for some glutamate synthesis even under conditions of nitrogen excess. The comparatively high Michaelis constant of AD for ammonia (Table I) makes it unlikely that ammonia was incorporated into bacteria by means of the reaction catalysed by this enzyme.

The glucose-limited organisms also contained high GD activity when ammonia was the sole source of nitrogen, and the significant difference between these and the magnesiumlimited bacteria was in the AD levels. When the organisms were grown on the same nitrogen source and at the same growth rate, in every case the levels of AD in carbon-limited bacteria were higher than in magnesium- or nitrogen-limited bacteria (Table 2).

Ammonia-limited organisms produced high levels of GOGAT. This is consistent with the suggestion of Meers et al. (I97I) that GOGAT is necessary for ammonia assimilation under conditions where the extracellular ammonia concentration is extremely low.

When glucose was replaced by alanine as the energy source for a carbon-limited culture, much ammonia was excreted by the bacteria and the AD level increased markedly (Table 2). Thus it seemed that alanine was catabolized directly to pyruvate and ammonia. However, the availability of alanine as a substrate was not in itself the only factor prescribing high AD levels; nitrogen-limited organisms, metabolizing alanine as the growth-limiting nitrogen source, had a comparatively low specific activity of AD (Table 2). The pool alanine concentrations in the carbon (alanine)- and nitrogen (alanine)-limited cultures were similar (i.e. both between 3 and $4 \mathrm{~mm}$ at a dilution rate of $0.2 \mathrm{~h}^{-1}$ ). 


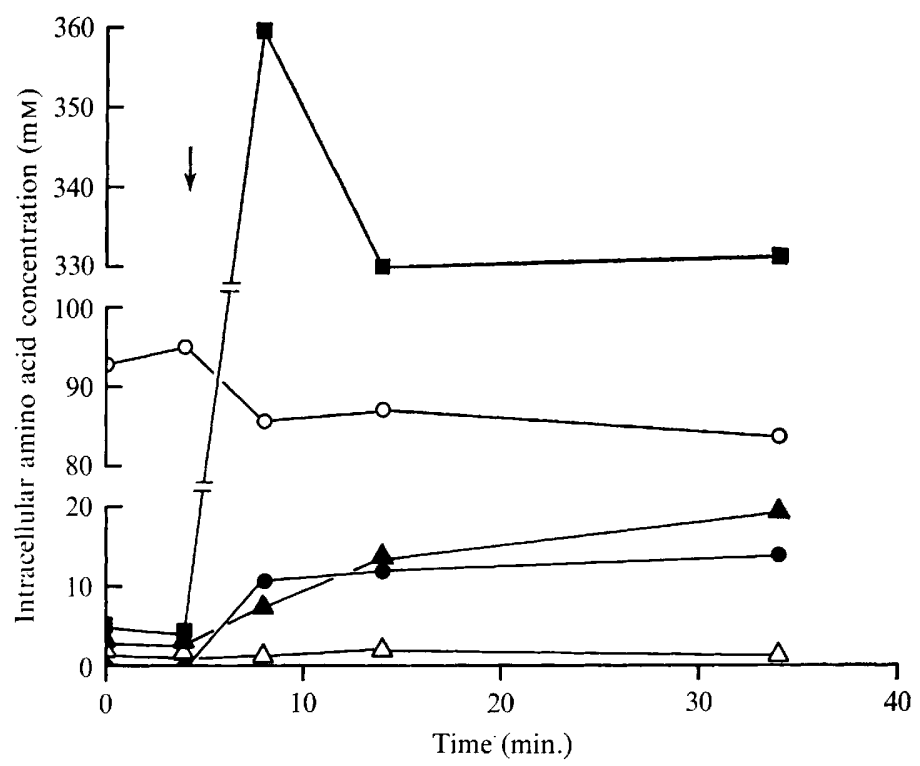

Fig. I. Changes in the pool concentrations of ammonia $(\boldsymbol{\square})$, glutamate $(0)$, glutamine (O), aspartate $(\triangle)$ and alanine $(\Delta)$ following the addition of $\left(\mathrm{NH}_{4}\right)_{2} \mathrm{SO}_{4}$ (approximately $30 \mathrm{~mm}$ final concentration) to a steady-state nitrogen (ammonia)-limited culture of Bacillus licheniformis growing in a chemostat at a dilution rate of $0.2 \mathrm{~h}^{-1}\left(34^{\circ}, \mathrm{pH} 7.0\right.$, carbon source glucose). An arrow marks the time when the sterile $\left(\mathrm{NH}_{4}\right)_{2} \mathrm{SO}_{4}$ solution was added to the culture.

Changes in 'pool' amino acid contents and enzyme activities of Bacillus licheniformis following the addition of specific substrates to growing cultures

To investigate further the routes involved in amination and deamination in Bacillus licheniformis, solutions of several key substrates were pulsed into the chemostat cultures and subsequent changes in amino acid pool content and distribution were observed. These results were then correlated with concomitant changes in the specific activities of $A D, G D$ and GOGAT.

Under ammonia-limited growth conditions the organisms contained measurable quantities of AD, GD and GOGAT when grown at a dilution rate of $0.2 \mathrm{~h}^{-1}$ (Table 2). Excess ammonia pulsed into such a culture effected a rapid, 200-fold increase in the concentration of glutamine. This result is consistent with the previously reported observation that nitrogenlimited bacteria contain high concentrations of glutamine synthetase (Meers \& Tempest, 1970), and that the initial step in amination under these growth conditions is the formation of glutamine. However, in Bacillus licheniformis there then followed a gradual accumulation of alanine (Fig. I) but not glutamate. This alanine could have been formed by transamination from glutamate, or by reductive amination from ammonia, or conceivably by the reductive transfer of the amide group of glutamine to pyruvate by a reaction analogous to that catalysed by GOGAT. The latter possibility was examined directly and found not to occur.

When alanine was pulsed into a glucose-limited culture in which ammonia was the nitrogen source, then deamination of an amino acid was necessary before the alanine could be metabolized as an energy source. The removal of ammonia from alanine could occur either by direct deamination of alanine or by the deamination of glutamate following a 


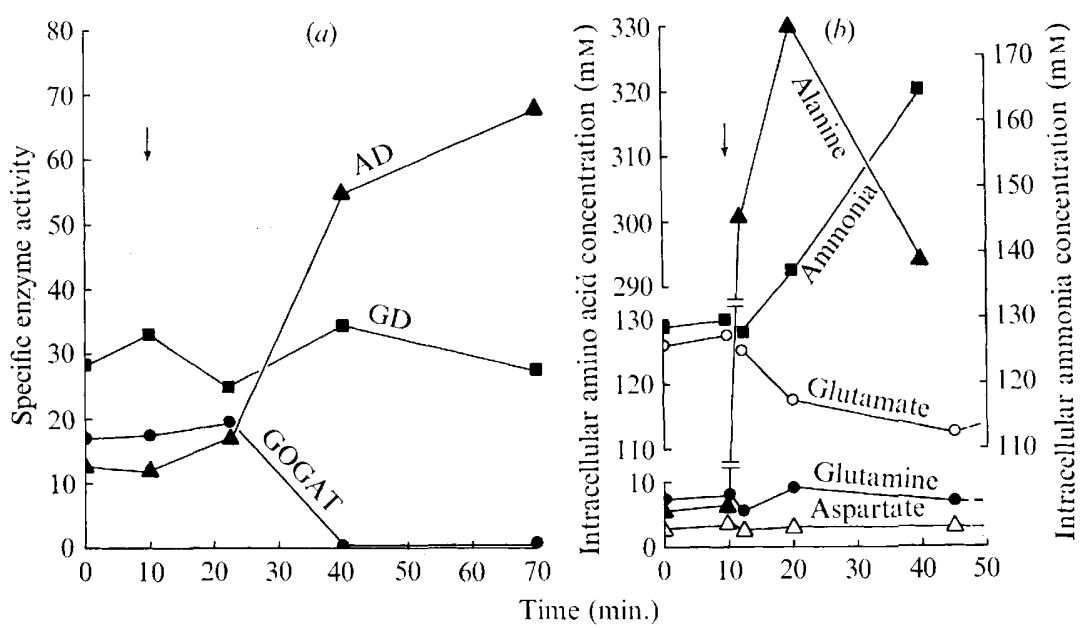

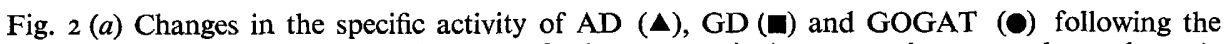
addition of alanine (approximately $30 \mathrm{~mm}$ final concentration) to a steady-state carbon (glucose)limited culture of Bacillus licheniformis growing in a chemostat at a dilution rate of $0.2 \mathrm{~h}^{-1}\left(34^{\circ}\right.$, $\mathrm{pH} 7 \cdot 0$, nitrogen source $\mathrm{NH}_{3}$ ). The units of GD and GOGAT activity are expressed as nmoles/ $\mathrm{min} / \mathrm{mg}$ protein, and the units of $\mathrm{AD}$ activity as moles ${ }^{-5} / \mathrm{min} / \mathrm{mg}$ protein. An arrow marks the time of addition of alanine.

(b) Changes in the pool concentration of ammonia $(\square)$, glutamate $(O)$, glutamine $(0)$, aspartate $(\triangle)$ and alanine $(\Delta)$ following the addition of alanine to a Bacillus licheniformis culture. The details of this experiment were as described in Fig. $2(a)$.

transamination reaction between 2-oxoglutarate and alanine, as suggested by Shen, Hong \& Braunstein (1959). In fact, the alanine pulse stimulated a rapid increase in the concentration of $\mathrm{AD}$, but caused no significant change in the concentration of GD (Fig. 2a). This indicated that alanine was deaminated directly to pyruvate and ammonia. This conclusion was reinforced by the finding that the extracellular and intracellular concentrations of alanine decreased to a steady-state level in $3 \mathrm{~h}$ at the same time as the pool, and extracellular, ammonia concentrations increased. During this $3 \mathrm{~h}$ period there was no increase in the pool concentration of glutamate; indeed, during the first hour the pool glutamate level decreased (Fig. $2 b$ ).

When glutamate ( $30 \mathrm{~mm}$ final concentration) was pulsed into a glucose-limited culture instead of alanine, there was some increase in the level of GD, but little change in the specific activities of AD or GOGAT (Fig. $3 a$ ). The period when the greatest specific activities of GD were evident coincided with the time of maximum ammonia production (Fig. $3 b$ ). This result was thus analogous to that obtained when alanine was added to a carbonlimited culture, but the changes were quantitatively not as marked.

The changes which occurred when the bacteria were taken from conditions of nitrogen excess to nitrogen limitation are shown in Fig. 4. Glucose (20 mm final concentration) was pulsed into a glucose-limited culture containing alanine as its sole nitrogen source. At the same time as the pulse was added, the medium was changed so as to bring about ammonialimited growth conditions after a short period of unrestricted growth. This experiment was thus essentially the reverse of the alanine pulse experiment illustrated by Fig. I, and the results of the two experiments were complementary. On becoming nitrogen-limited the level 


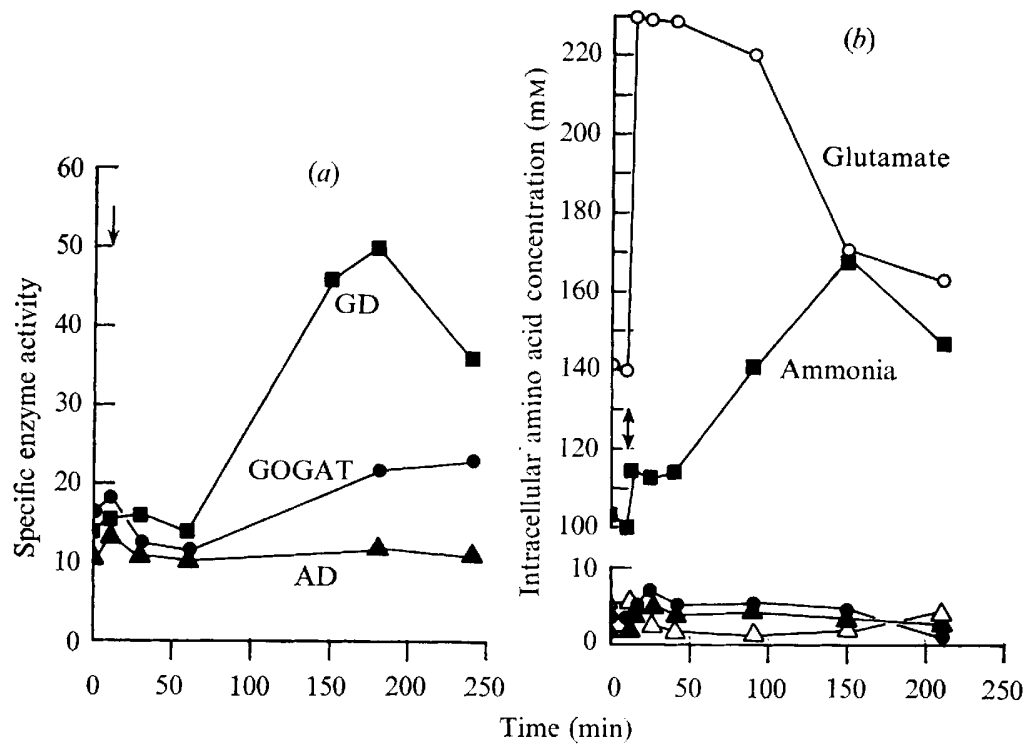

Fig. 3. Changes in (a) specific enzyme activity and $(b)$ the amino acid pool of Bacillus licheniformis organisms following the addition of sodium glutamate (approximately $20 \mathrm{~mm}$ final concentration) to a carbon (glucose)-limited chemostat culture (dilution rate $0.2 \mathrm{~h}^{-1}, 34^{\circ}, \mathrm{pH} 7.0$, nitrogen source $\mathrm{NH}_{3}$ ). The symbols and units of specific enzyme activity are as described for Fig. 2.

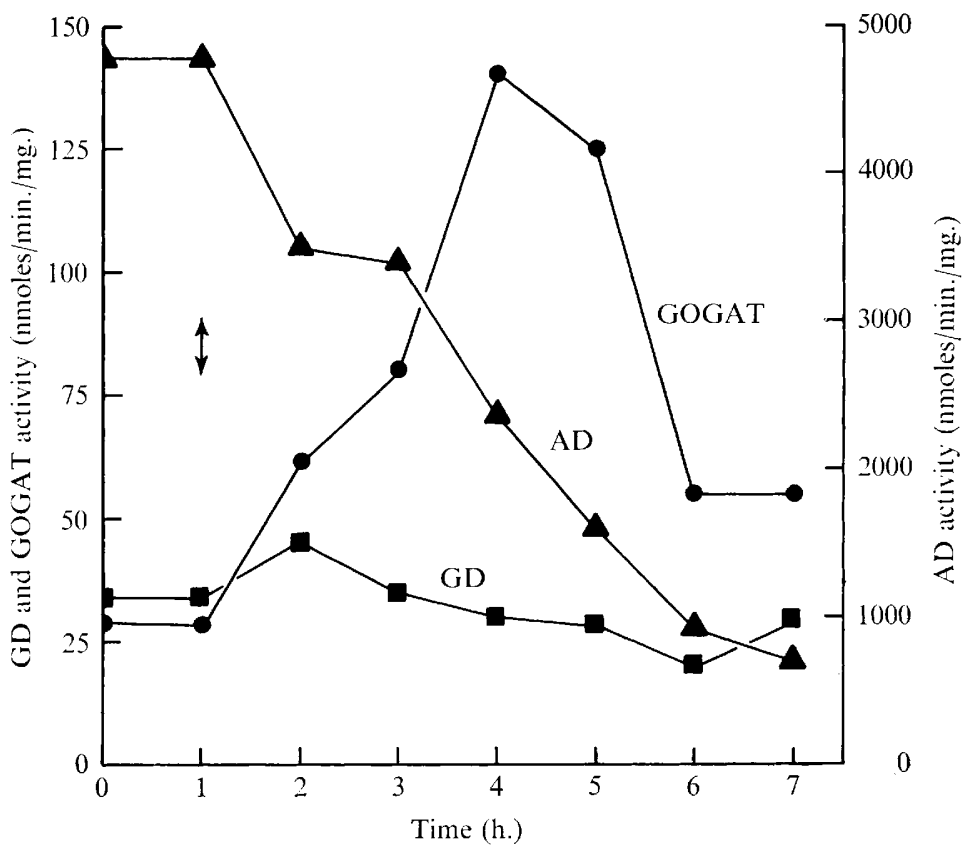

Fig. 4. Changes in the specific activity of $\operatorname{AD}(\Delta)$, GD $(\boldsymbol{\square})$ and GOGAT $(\boldsymbol{O})$ following the change of a Bacillus licheniformis culture from carbon to nitrogen-limited growth conditions. At the time marked by an arrow excess sterile glucose solution was added to the culture, and at the same time the medium entering the chemostat was changed from that designed to produce carbon-limited growth with alanine as the carbon source to that producing ammonia-limited growth in the chemostat with glucose as the carbon source. The dilution rate was maintained at $0.2 \mathrm{~h}^{-1}$ throughout the experiment. 
of $\mathrm{AD}$ in the organisms fell sharply, whereas the level of GOGAT reached a transient peak level that was substantially higher than was observed at any other time during the course of this work. The level of GD again did not change significantly.

\section{DISCUSSION}

The properties of AD, GD, and GOGAT, extracted from Bacillus licheniformis were similar to those from other species of Bacillus (see, for example, Yoshida \& Freese, 1965; Meers et al. I97I). From these data alone it is not possible to be sure which reactions they do in fact catalyse in vivo. As a result of growing $B$. licheniformis in a chemostat under steady-state conditions, and then noting the changes which occurred following a controlled disturbance of the dynamic equilibrium of the cultures, roles can be suggested for these three functionally related enzymes.

It has previously been suggested that GOGAT functions, in ammonia-limited Aerobacter aerogenes, as an integral part of a cyclic mechanism which leads to the assimilation of low concentrations of ammonia (Tempest et al. 1970). Recent work by Elmerlich \& Aubert (I97I) leads to the suggestion that $\mathrm{GD}^{-}$strains of Bacillus megaterium synthesized glutamate by the same mechanism. The present results are consistent with these conclusions. Thus, low concentrations of ammonia derepressed GOGAT synthesis (Table 2; Fig. 4), but an increase in the concentration of glutamate in the amino acid pool of Bacillus licheniformis did not significantly affect GOGAT synthesis (Fig. 3), showing that the synthesis of this enzyme was not subject to end-product repression. However, the pool glutamate level was invariably high (see Fig. 2-4), and this could explain why quantitatively large, but proportionately small, changes in glutamate concentration did not have as marked an effect on enzyme synthesis as did quantitatively similar, but proportionately larger increases in the initially low pool alanine concentration (compare Fig. 2 and 3). Thus, one important factor influencing both the levels of GOGAT activity in $B$. licheniformis organisms and the specific activity of glutamine synthetase measured in A. aerogenes organisms (Meers \& Tempest, 1970) was the availability of ammonia. Since both enzymes are co-operatively concerned in glutamate synthesis, under ammonia-limited growth conditions, this result is predictable. However, the activity of glutamine synthetase is also subject to complicated control by enzyme-catalysed chemical modification (Holzer et al. 1970), and Deuel et al. (1970) have shown that glutamine synthetase synthesis in Bacillus subtilis is derepressed by ammonia-limitation. Therefore the activity of this enzyme seems primarily to control the flux of metabolites at this important linkage point between carbon and nitrogen metabolism in bacteria.

The control and function of GD synthesis in Bacillus licheniformis cannot be as readily explained. Tempest et al. (1970) and Meers et al. (197I) concluded that GD functioned in ammonia incorporation under growth conditions of ammonia excess when the high $K_{m}$ of this enzyme for ammonia did not restrict its activity. The present results (Tables I, 2) are consistent with those reported previously with other species of bacteria (Meers et al. 197I), but in addition it was observed that when glutamate was added to a carbon-limited chemostat culture then the specific activity of GD increased and direct deamination of glutamate took place (Fig. 3). Thus, GD functions (at least in B. licheniformis) in either an aminating or in a deaminating direction, and thereby operates as a 'valve', preventing an excessive increase in the pool glutamate level. This latter function is in addition to that previously suggested (Tempest et al. 1970).

No evidence was obtained to support the suggestion (Fairhurst, King \& Sewell, 1956; 
Hong et al. 1959; Shen et al. 1959; Goldman, 1959; Freese \& Oosterwyk, 1963; Meister, 1965; Germano \& Anderson, 1968) that AD plays a significant role in incorporating free ammonia into cellular protein. Preparations of AD extracted from various bacteria invariably have a high $K_{m}$ value for ammonia (Wiame et al. 1962; Yoshida \& Freese, 1965), and the value found for Bacillus licheniformis was $300 \mathrm{~mm}$ (Table I). However, the organisms could grow and assimilate ammonia when the intracellular ammonia concentration was less than I mM (Fig. I and Tempest et al. I97I), at which concentration no AD activity could be measured in vitro (J. L. Meers \& L. K. Pederson, unpublished observation). Under ammonia-limited growth conditions the enzymes involved in ammonia assimilation would probably be derepressed; under these conditions the specific activity of AD was small (Table 2). AD was, however, synthesized to a greater extent when the organisms were carbon-limited, and the highest specific activity for this enzyme was measured in organisms provided with alanine as the sole energy source for a carbon-limited culture. However, the availability of alanine as a substrate was not the sole factor prescribing high AD levels, because nitrogenlimited organisms metabolizing alanine as the growth-limiting nitrogen source in the presence of excess glucose had a comparatively low specific activity of AD (Table 2). These results infer that AD synthesis was repressed by the presence of catabolites and induced (or derepressed) by alanine. The catabolic activity of $\mathrm{AD}$ was furthermore subject to severe end-product inhibition by pyruvate, but not by ammonia. The results reported here strongly support the conclusion that the essential physiological function of $\mathrm{AD}$ is to catabolize L-alanine to produce pyruvate which can then readily be used as a carbon and energy source.

We are most grateful to Miss L. Priem Pedersen for her skilled assistance, and to Mr J. Markussen for carrying out the amino acid analyses.

\section{REFERENCES}

Deuel, T. F., Ginsburg, A., Yeh, J., Shelton, E. \& Stadtman, E. R. (1970). Bacillus subtilis glutamine synthetase: purification and physical characterization. Journal of Biological Chemistry 245, 5195-5205.

Dixon, M. \& WeBb, E. C. (I964). Enzymes, 2nd edn. London: Longmans Green.

Elmerlich, C. \& AUBert, J. (I97I). Synthesis of glutamate by a glutamine: 2-oxo-glutarate amidotransferase (NADP oxidoreductase) in Bacillus megaterium. Biochemical and Biophysical Research Communications 42, 37I-376.

Evans, C. G. T., Herbert, D. \& Tempest, D. W. (1970). The continuous cultivation of micro-organisms. II. Construction of a chemostat. In Methods in Microbiology, vol. 2, pp. 277-328. London and New York: Academic Press.

Fairhurst, A. S., King, H. K. \& Sewell, C. E. (1956). Studies in amino acid biogenesis: the synthesis of alanine from pyruvate and ammonia. Journal of General Microbiology 15, 106-120.

Freese, E. \& OOSTERWyK, J. (I963). The induction of alanine dehydrogenase. Biochemistry 2, I2I2-I 2 I 6.

Germano, G. J. \& Anderson, K. E. (1968). Purification and properties of L-alanine dehydrogenase from Desulfovibrio desulfuricans. Journal of Bacteriology 96, 55-60.

Goldman, D. S. (1959). Enzyme systems in the Mycobacteria. VIII. Purification, properties and mechanism of action of the alanine dehydrogenase. Biochemica et biophysica acta 34, 527-539.

Holzer, H., Mecke, D., Leiss, D., Wulff, K., Heilmeyer, L. Jun., Ebner, E., Gancedo, C., Schutt, H., Battig, F. A., Heinrich, F. A. \& Wolf, D. (1970). Enzyme-catalysed modification of glutamine synthetase from E. coli. FEBS Symposium I9, I 7 I-I 77 .

Hong, M. M., Shen, S. C. \& Braunstein, A. E. (1959). Distribution of L-alanine dehydrogenase and L-glutamate dehydrogenase in Bacilli. Biochemica et biophysica acta 36, 288-289.

MeERs, J. L. \& TEMPEST, D. W. (1970). Regulation of glutamine synthetase synthesis in some Gram-negative bacteria. Biochemical Journal Ir9, 603-605.

Meers, J. L., Tempest, D. W. \& Brown, C. M. (I97I). 'Glutamine(amide): 2-oxoglutarate amino transferase oxido-reductase (NADP)', an enzyme involved in the synthesis of glutamate by some bacteria. Journal of General Microbiology 64, I87-194. 
MeISTER, A. (1965). Biochemistry of Amino Acids, vol. 2, p. 480. Basel: Karger.

Pí́rard, E. \& WiAme, J. M. (1960). Proprietés de la L-(+)-alanine dehydrogenase. Biochemica et biophysica acta 37, 490-502.

PIRT, S. J. (1957). The oxygen requirement of growing cultures of an Aerobacter species determined by means of the continuous culture technique. Journal of General Microbiology 16, 59-75.

Shen, S. C., Hong, M. M. \& Braunstein, A. E. (I959). The main path of nitrogen assimilation in Bacillus subtilis. Biochemica et biophysica acta 36, 290-291.

StICKLAND, L. H. (195I). The determination of small quantities of bacteria by means of the biuret reaction. Journal of General Microbiology 5, 698-703.

Tempest, D. W., Meers, J. L. \& Brown, C. M. (1970). Synthesis of glutamate in Aerobacter aerogenes by a hitherto unknown route. Biochemical Journal Ir7, 405-407.

Tempest, D. W., MeERS, J. L. \& BRown, C. M. (I971). Influence of environment on the content and composition of microbial free amino acid pools. Journal of General Microbiology 64, $17 \mathrm{I}-185$.

Wiame, J. M., Piérard, A. \& Ramos, F. (1962). L-Alanine dehydrogenase from Bacillus subtilis. In Methods in Enzymology, vol. 5, pp. 673-676. Edited by S. P Colowick \& N. O. Kaplan. London and New York: Academic Press.

YoshidA, A. \& Freese, E. (1965). Enzymic properties of alanine dehydrogenase of Bacillus subtilis. Biochemica et biophysica acta 96, 248-262. 